\title{
AS REPRESENTAÇOEES POPULACIONAIS DE RICHARD FRANCIS BURTON - UMA ANÁLISE DO PROCESSO DE CONSTITUIÇÃO DO DISCURSO SOBRE POPULAÇÕES NÃO EUROPÉIAS NO SÉCULO XIX'
}

\author{
Alexsander Lemos de Almeida Gebara \\ Doutorando - História Social - FFLCH/USP
}

\section{Resumo}

Este artigo procura compreender as transformações nas descrições populacionais de Richard Burton entre 1849 e 1869. A hipótese principal é que a compreensão mais efetiva destas representações só é possível quando analisa-se fatores como a motivação e a experiência da viagem e o lugar de autoridade do enunciador do discurso

\section{Abstract}

This text intend to understand the transformations on the populational descriptions of Richard Burton between 1849 and 1869. The central hypothesis is that a more effective comprehension of those representations is possible when one analyses several issues like the motivations and the experience of the travel and the locus of authority of the writer

\section{Pallavras-Chave}

Relatos de Viagem • Descrições Populacionais • Análise do Discurso

\section{Keywords}

Travel Writings • Populational Descriptions • Discourse Analysis

\footnotetext{
${ }^{1}$ Este artigo foi baseado em minha dissertação de mestrado "A Experiência do Contato. As Descrições Populacionais de Sir Richard Francis Burton", defendida no Depto. de História-FFLCH/USP em dezembro de 2001, financiada pela CAPES. O material entretanto sofreu algumas alterações oriundas de minha pes-
} 


\section{Apresentação}

Este texto tem como objetivo analisar as transformações nas descrições populacionais de Richard Francis Burton ao longo do tempo, de forma a compreender melhor as representações realizadas pelo autor ao longo de sua vida. Somente a partir da observação da experiência de cada viagem torna-se possível compreender de maneira efetiva o conteúdo de suas descrições e a evolução das conceituações do autor. A hipótese é que tanto seu repertório cultural, quanto a posição de autoridade na qual o narrador se coloca para escrever o relato e a experiência da própria viagem são elementos que interagem no resultado final do texto, e que devem ser analisados para evitar simplificações excessivas. Logo, uma das intenções deste trabalho é mostrar a importância da compreensão do processo de construção de conceitos determinados, no caso a representação da população, para que se torne possível analisar com mais clareza os relatos de Richard Burton.

\section{Richard Francis Burton}

Primeiro filho de Joseph Burton, tenente do exército inglês, Richard nasceu em Torquay, Inglaterra, em 1821. Aos vinte e um anos, após uma breve e frustrada experiência acadêmica em Oxford, seu pai comprou-lhe um posto de oficial na Companhia das Índias Orientais, tendo assim seguido para a Índia para servir no $16^{\circ}$ regimento nativo de Bombaim.

Burton esteve no continente indiano por cerca de sete anos, justamente num período de políticas anexacionistas agressivas por parte da Inglaterra, que ampliava seus domínios na Índia, agregando os territórios de Scind (em 1842) e Punjab (em 1846 - 49). Foi exatamente para o território de Scind (hoje parte do Paquistão), recém anexado, que Burton se dirigiu em seus primeiros meses no Oriente.

Durante seus anos na Índia, dedicou-se ao aprendizado de línguas e dialetos locais. Graças a seu conhecimento destas línguas, desempenhou funções de espionagem, imiscuindo-se entre os nativos para conseguir informações para a Inteligência do exército da Companhia.

quisa de Doutorado no mesmo departamento, intitulado "O discurso de Richard Francis Burton sobre as regiões periféricas, uma analise do processo de construção de suas representações". 
Ainda em território inglês na Índia, Burton tomou contato com preceitos da religião islâmica e aperfeiçoou seus conhecimentos na língua árabe, que seriam importantes para suas futuras viagens à África Oriental e Península Arábica. Desta sua permanência no continente resulta um dos relatos que serão utilizados como fontes neste texto, trata-se de Goa and the blue mountains or six months of sick leave (Burton, 1991a) publicado originalmente em 1849 na Inglaterra.

Suas duas viagens seguintes tiveram caráter bastante diferente. De licença da Companhia, financiado pela Royal Geographical Society, disfarçado de muçulmano, e despendendo apenas alguns meses em cada uma, Burton realiza a peregrinação mais sagrada para os islâmicos em 1853 e, no ano seguinte, parte para conhecer a cidade de Harar, também grande centro muçulmano e importante entreposto comercial da região oriental africana.

O financiamento da $R$. G. S. para estas viagens é bastante esclarecedor quanto aos objetivos explícitos destes empreendimentos, quais sejam, tornar conhecidas regiões estranhas à Europa, preencher vazios nos mapas europeus e possivelmente abrir caminho para o desenvolvimento de atividades comerciais. Além disto, a relação entre a $R$. G.S. e o Império britânico são praticamente diretas. Segundo Robert Stafford, "durante todo o século dezenove, a Inglaterra sustentou um programa de exploração científica ligado diretamente com seus interesses comerciais e imperiais" (Stafford, 1999 : 294).

Ainda da década de 50 do século XIX, Burton realiza outra viagem à África, também financiada pela Royal Geographical Society, buscando a nascente do Nilo. Durante esta expedição, penetra pela região da atual Tanzânia, atingindo o "mar de Ujiji”, rebatizado por ele de Lago Tanganika.

Em 1860, casou-se com Isabel Arundell, e no ano seguinte foi nomeado cônsul inglês em Fernando Pó, permanecendo em suas funções até o ano de 1865, quando foi transferido para o porto de Santos, no Brasil. Em cada uma destas viagens, Burton produziu ao menos um relato, que fazem parte do corpo de fontes que serão utilizadas neste artigo.

Burton faleceu no ano de 1890, após outras experiências consulares em Damasco e Trieste. Ao longo de sua vida, dedicou-se em especial ao estudo de línguas não européias e à tradução de importantes obras literárias para o inglês, entre elas a grande obra erótica oriental "Kama Sutra”, um conjunto de contos Hindus denominado "Vikram e o vampiro", "os Lusíadas" de Camões, e muitas outras, incluindo algumas de literatura brasileira como Iracema e $O$ Guarani. 
Com sua morte, sua esposa Isabel, católica fervorosa, trancou-se em seu gabinete pessoal, selecionou grande parte dos seus escritos não publicados e queimou os que foram considerados por ela como agressivos à moral, procurando dissociar a imagem de Burton da literatura erótica oriental.

Serão analisadas neste artigo as descrições populacionais presentes nos livros sobre suas viagens a Meca, Harar, África Central, África Ocidental e Brasil, além do já mencionado relato da viagem para Goa, com a intenção de tornar mais compreensível os diferentes juízos emitidos pelo autor no que diz respeito às populações não européias descritas nestes textos. Desta forma, as análises serão apresentadas em sua seqüência temporal, de maneira que torne-se possível notar mais claramente as transformações em suas descrições ao longo do tempo.

\section{Um militar inglês na Índia}

Para que se possa compreender as representações de Burton a respeito das diferentes populações que descreve em Goa and the blue Mountains, é preciso, primeiramente, recuperar o lugar de autoridade no qual ele se coloca para narrar suas aventuras em terras indianas. E, de fato, pode-se notar, já no primeiro capítulo, a clara delimitação do lugar de todos os envolvidos na dinâmica do relato, quais sejam, os habitantes nativos, o próprio autor e, finalmente, o leitor europeu, mais especificamente inglês.

Burton procurou valorizar sua experiência de cinco anos em terras orientais através da constante referência a elementos do cotidiano na Índia que soam incompreensíveis ao leitor europeu. De fato, já no primeiro parágrafo do texto pode-se notar claramente esta estratégia. Estando de saída da "pestilenta" Scinde, embarca em seu Pattimar,

"Seu o que?,

Ah!, esquecemo-nos. A Gôndola e a barca são palavras comuns para seus ouvidos ingleses, o budgerow começa a ganhar familiaridade, mas você está certo, o pattimar requer uma definição"(Burton, 1991a: 1).

Ao mesmo tempo em que se aproxima do leitor e identifica-o, tratando-lhe por "você" e dirigindo-se a "ouvidos ingleses", Burton assume a sua posição privilegiada 
em razão de seu conhecimento do lugar que descreve. Ele faz questão de se mostrar tão próximo da realidade colonial que até mesmo "se esquece" de que o leitor poderia não conhecê-la.

Mais importante, entretanto, para a compreensão das descrições populacionais presentes neste relato é o lugar no qual o autor se coloca frente ao nativo indiano, pois é a partir dele que lhe seria possível construir a idéia de manutenção do império inglês na Índia. E quanto a esta questão, Burton não nos deixa dúvidas. Segundo ele, o domínio inglês nas regiões orientais era um "império assentado na opinião", ou seja, "baseado na boa opinião que os nativos têm de nós e na sua má opinião para com eles mesmos". (Burton, 1991a : 157) No texto, portanto, o nativo submetese ao colonizador; ele não só considera o europeu superior, como também frente a ele cria uma imagem negativa de si mesmo.

Esta dupla posição de autoridade, em relação ao leitor e à própria população nativa, proporciona as condições para que o autor possa criar seu oriente. O leitor não conhece a Índia, e os indianos reconhecem-no como senhor. Não importa de fato a relação entre a descrição de Burton e a realidade observada, é o autor do texto que domina a cena e confere-lhe significação. A imagem oferecida da população colonial está, certamente, submetida a essas prerrogativas.

Tendo em vista essas colocações, é possível partir para a análise das descrições propriamente ditas. Pode-se perceber claramente em Goa and the blue Mountains três diferentes abordagens quanto à descrição populacional, condicionadas de certa forma pelo próprio itinerário da viagem: a primeira delas diz respeito à população sob domínio português, cujas observações tiveram lugar durante sua passagem por Goa; a segunda aparece quando Burton entra em domínios ingleses; e na terceira pode-se observar a descrição de povos ditos "selvagens", habitantes das montanhas azuis, lugar onde estava instalado o balneário inglês e onde Burton passou boa parte de seus meses de licença.

Segundo Burton, "a população de Goa é composta de três elementos heterogêneos, a saber, portugueses puros, cristãos negros e pagãos" (Burton, 1991a: 36). A separação mais clara, e a primeira que aparece, é entre Europeus "puros" e os demais habitantes. A referência aos portugueses trata exclusivamente da condenação da política de casamentos inter-raciais. De fato, a própria adjetivação "puro", que acompanha a separação entre portugueses e demais habitantes, e algumas outras passagens 
mencionando a degeneração dos mestiços e criticando a política de miscigenação poderiam indicar unicamente uma crítica do resultado "biológico" do cruzamento de "raças", entretanto, uma leitura mais atenta tende a relativizar essa interpretação.

De acordo com as concepções manifestadas por Burton neste momento, mesmo que não houvesse mistura de sangue, havia " a mistura de ar ou clima, o que vem a ser a mesma coisa" (Burton, 1991a: 89). Sua crítica parece muito mais direcionada à relação de proximidade estabelecida pelo antigo colonizador português com o indiano colonizado - resultado da política de casamentos - do que propriamente à mistura de sangue; ainda mais quando se pensa no caráter do "império de opinião" avalizado pelo autor, que se baseava justamente na demonstração de diferença e superioridade por parte do conquistador europeu.

Seguem-se, na caracterização do autor da população goesa, os outros dois "elementos heterogêneos". Sob a classificação de "cristãos negros", agrupam-se duas ordens diferentes, hindus convertidos e mestiços euro-indianos, e sua descrição se limita a algumas referências à sua feiúra e degradação ${ }^{2}$. Finalmente, a referência aos "pagãos" também se resume a poucas palavras: os hinduístas são fisicamente descritos unicamente por uma menção à pele amarelada, seguida da divisão interna das castas, e, aos muçulmanos, Burton reserva apenas um parágrafo:

“A população muçulmana em Panjim [Nova Goa] dificilmente chega a mil. [...] A marca distintiva dos fiéis é a longa barba. Eles parecem seres superiores ao lado dos degenerados cristãos nativos." (Burton, 1991a: 106)

Notem-se algumas características da divisão realizada por Burton neste primeiro momento, quais sejam: a divisão dos elementos é em si heterogênea, incluindo fatores geográficos (Europeus) e religiosos, e não funciona quando se pensa em termos de hierarquia social, pois os mestiços estão presentes em "todas as classes" segundo o próprio autor. Finalmente, não se pode pensar unicamente em critérios

\footnotetext{
${ }^{2}$ Sobre os mestiços , a referência é: "seria difícil encontrar na Ásia uma raça mais feia ou de aparência mais degradada", (Burton, 1991a: 97) enquanto os cristãos hindus são "decididamente a raça mais baixa na escala da humanidade civilizada que já tivemos oportunidade de descrever até agora" (Burton, 1991a: 103).
} 
"biológicos", pois as descrições físicas são muito reduzidas e carecem de elementos de comparação entre elas.

Esta é uma divisão totalmente exterior aos próprios nativos, sua hierarquia, seus valores e suas auto-definições não aparecem. Trata-se de uma divisão totalmente européia, ou seja, são critérios unicamente europeus que orientam a observação.

O que parece relativamente claro nesta parte do relato é que Burton está traçando um exemplo negativo de colonização ao descrever a situação das regiões coloniais portuguesas no continente. Os ingleses deveriam partir para a conquista efetiva, como vinham fazendo, e não somente dominar as rotas de comércio como fizeram anteriormente os portugueses. A capacidade de conquistar e o reconhecimento dela por parte do nativo são elementos importantes para a manutenção do "império de opinião". O retrato degenerado dos convertidos ao cristianismo serve para corroborar a crítica de Burton à prática portuguesa da conversão praticamente forçada. Mas, principalmente, os ingleses deveriam manter uma segura distância frente aos nativos, para que fosse possível preservar intacta a imagem de superioridade gerada pela conquista. Em passagem mais que reveladora da importância conferida à imagem que o hindu faz do europeu para a manutenção do domínio na região, o autor menciona que "todos sabem que, se o povo da Índia pudesse ser unânime por um dia, eles poderiam varrer-nos de seu país como poeira frente ao furacão" (Burton, 1991a: 161).

A partir do momento em que Burton entra em domínios ingleses, o tom da descrição muda completamente. Nota-se um interesse muito maior pela compreensão dos valores da população hindu. As descrições, embora continuem exteriores pelo simples fato de que são realizadas por um estrangeiro, buscam recuperar marcos e divisões da sociedade observada. Assim, a história que surge para os leitores não é mais a da conquista, como no caso da região sob domínio português, mas a própria interpretação hindu ${ }^{3}$.

\footnotetext{
${ }^{3}$ Entrando na província de Malabar, Burton resume sua origem da seguinte maneira: "A província, agora chamada Malabar, é parte do Kerula Rayja, o reino de Kerula, uma das dezesseis deshas ou regiões, enumeradas na antiga história hindu como formando a Bharata Khanda, ou terra da Índia. Supõe-se que ela foi coberta pelo mar na sexta encarnação de Vishnu, o qual, em expiação a um matricídio, deu aos brâmanes, particularmente àqueles da tribo monsut, as amplas terras entre Gokarna e Cabo Camorin”. (Burton, 1991a: 186). Não interessa o status que Burton confere a esta história, aparentemente fabulosa, mas sim o fato de que, de alguma forma, importava recuperá-la.
} 
No momento da descrição populacional, esta mudança parece também evidente, a classificação agora procurava reproduzir a hierarquia social dos próprios hindus, mencionando casta por casta, seus costumes e as suas relações sociais com as outras. É importante notar que as referências às características físicas continuam muito breves e imprecisas, e que a própria definição da Índia como "terra das maravilhas etnológicas" é significativa de que sua atenção está voltada apenas para os costumes e crenças da população, e não para suas supostas características "raciais". (Burton, 1991a: 212)

A descrição apresentada por Burton da população sob domínio inglês traz, portanto, significativas diferenças em relação àquela sob domínio português. Seu plano de manutenção do domínio inglês na Índia já estava traçado e, como se viu, pautavase na afirmação de uma boa imagem do europeu por parte do indiano. Nesta parte do livro, Burton dedica-se muito mais à tentativa de compreensão do funcionamento da sociedade do "outro". Embora não esboce nenhuma estratégia de ação para criação de uma imagem positiva do inglês, o esforço de compreensão realizado pelo autor nestas passagens é significativo frente a seu projeto demonstrado anteriormente.

Resta, pois, a descrição dos povos "selvagens" das montanhas azuis, os últimos descritos pelo autor neste relato. Novamente, mudam-se os parâmetros descritivos. Os cerca de dez mil "selvagens" das montanhas não representavam problema efetivo para as pretensões de domínio inglês, e sua descrição estaria de certa forma livre das preocupações imperiais do autor. Será muito interessante, entretanto, recuperar quais os elementos julgados importantes pelo autor para caracterizar esta população selvagem, para que se possa vislumbrar quais poderiam ser suas filiações teóricas neste momento quanto à concepção sobre populações não européias.

De fato, mencionar-se-á aqui apenas a descrição dos chamados Todas, habitantes mais numerosos e antigos segundo Burton, e aos quais ele dá maior atenção. A sua primeira preocupação foi buscar recuperar a origem desta população e, num debate com vários outros autores que anteriormente haviam descrito os Todas e supunham para eles uma ancestralidade européia, Burton sugeria contrariamente que:

"Os todas são meros remanescentes das velhas tribos Tamulians, originalmente habitando as planícies, e subseqüentemente empurrados às montanhas por algum evento, sobre o qual a história é silenciosa. Nossa opinião é construída sobre a rocha da linguagem. (Burton, 1991a: 342) 
A "rocha da linguagem", era esta a única fundação segura para que se pudesse afirmar com certeza a origem de um povo, e a língua dos Todas era uma derivação do sânscrito, assim como o hindustâni. Mesmo a diferença de pronúncia não era o suficiente para ir contra a semelhança entre vocábulos e gramática notada por ele. A rigor, nem as grandes dessemelhanças físicas e de costumes eram argumentos suficientes para desautorizar a sua asserção.

É também digno de nota que, embora não houvesse "nada em seus costumes que não fosse peculiar” (Burton, 1991a: 347), tais como cerimônias de nascimento, costumes infanticidas e poliandria entre outros, Burton consegue traçar uma imagem idealizada do "selvagem":

"Você que perceberia a visão da inocência nômade e da felicidade respeitável e sensata do selvagem - (como) uma doce alucinação que até agora você considerou como o mais louco sonho jamais emitido do portão de marfim - vá, encontreas nos cantos remotos da terra dos Toda, a fértil, a salubre." (Burton, 1991a: 350)

O reverso desta felicidade poderia ser visto, entretanto, na degeneração ocasionada pelo contato com populações civilizadas, que geravam a ruína moral dos selvagens, que abandonavam valores como a castidade, sobriedade e temperança e sucumbiam aos vícios da luxúria, da ganância, etc... (Burton, 1991a: 350). Notese, entretanto, que esta degeneração era ocasionada principalmente pela miscigenação cultural e não física.

A busca da origem baseada no instrumento linguiístico, "a rocha da linguagem", ou seja, a utilização da lingüística comparada no estudo de povos não europeus era característica da corrente etnológica mais influente na Inglaterra neste período do século XIX ${ }^{4}$.

Deve-se notar que os elementos recuperados nas descrições populacionais ao longo deste texto foram, em momentos diversos, a origem da população, seus cos-

\footnotetext{
${ }^{4}$ George Stocking sugere que na Inglaterra o termo etnologia estava primeiramente associado ao nome de James Prichard, que defendia idéias monogênicas, e cujo pensamento sobre a origem da humanidade estava bastante influenciado pelo relato bíblico. A filologia comparada era uma de suas principais ferramentas na sua guerra travada contra as concepções poligênicas especialmente influentes na França. (Stocking, 1987: 46 - 77).
} 
tumes, referências sobre a influência climática na configuração física e moral do povo, entre outros. Isto em detrimento de uma descrição formal mais detalhada, característica de uma antropologia física. A própria utilização do termo "etnologia" e não "antropologia" parece revelador das opções de Burton neste momento.

Sol Tax sugere que se poderia falar de uma "guerra dos trinta anos" na ciência do homem, entre 1840 e 1870, colocando-se de um lado do campo de batalha uma "etnologia", de caráter mais filosófico, histórico, e com uma conotação humanitária e, do outro lado, uma "antropologia" ligada ao desenvolvimento da biologia enquanto disciplina científica.(Tax, 1964) Mesmo que a utilização do termo por Burton pareça ocasional, pois não contém a conotação ideológica sugerida por Tax, não deixa de ser interessante notá-lo aqui, pois indica o instrumental descritivo mais facilmente disponível na Inglaterra da primeira metade do século XIX, já que, segundo vários autores, a etnologia, por sua vez associada à idéia de uma origem única da humanidade, predominava sobre a antropologia física no ambiente intelectual inglês neste período.(Gould, 1999, Stepan, 1987, Stocking, 1968, 1987)

\section{0 - 60 - A década de aventuras}

Em 1853, referindo-se às tribos beduínas da Península Arábica, Burton qualificava os nativos como "nobres selvagens", cujo caráter era "um composto verdadeiramente nobre de determinação, gentileza e generosidade" (Burton, 1964: 86, vol. 1), ou seja, o "selvagem" puro continuava apresentando características morais valorizadas na Europa. Por outro lado, no final desta década, em descrição da população da África Centro-oriental (região da atual Tanzânia), a referência a "selvagens" surgia de forma bastante diferente, segundo o autor

"ele parece[...] ao homem civilizado um ser paralógico, - uma mera massa de contradições, seus caminhos não são os nossos caminhos, sua razão não é a nossa razão. Ele deduz efeitos de causas que nós ignoramos." (Burton, 1995 : 490)

Há de fato uma grande mudança no juízo do autor para com os "selvagens", que se processa em um período relativamente curto de tempo. A análise das descrições populacionais do autor nos três relatos escritos nesta década, das ferramentas utilizadas por ele para construir a imagem da população descrita, e da própria 
experiência da viagem podem fornecer algumas pistas para que se compreenda esta transformação.

Quando Burton partiu para a Arábia, seu conhecimento a respeito da região já era bastante vasto, conhecia a língua árabe e os preceitos da religião islâmica com tal segurança que lhe foi possível realizar toda a viagem disfarçado de muçulmano. Edward Said menciona que

"ele era sobrenaturalmente instruído sobre a que ponto a vida humana em sociedade é regida por regras e códigos; Toda sua vasta informação sobre o Oriente, evidente em cada página que escreveu, revela que ele sabia que o oriente em Geral e o Islã em particular, eram sistemas de informação, comportamento e crença, que ser oriental era saber certas coisas de certa maneira, e que estas, é claro, estavam sujeitas à história, à geografia, e ao desenvolvimento da sociedade em circunstâncias que lhe eram específicas"(Said, 1990 : 203)

A descrição da população da península arábica pôde ser realizada pelo autor com base em conhecimentos anteriores que possuía, oriundos tanto de sua experiência de contato com populações muçulmanas da Índia, como de textos orientalistas europeus. De fato, o livro de Burton na Arábia funciona como afirmação da efetividade do conhecimento europeu produzido sobre o oriente, conferindo à Europa, portanto, um domínio textual efetivo destas regiões. O próprio fato de ter completado a viagem disfarçado de muçulmano e contado sua história confere grande autoridade ao conhecimento orientalista europeu.

A descrição mais estruturada e significativa presente neste relato é a que se refere aos beduínos da região próxima a Meca, e está dividida em duas partes principais, a primeira física e a segunda moral, colocadas logo em seguida a uma definição da suposta origem desta população. ${ }^{5}$

\footnotetext{
${ }^{5}$ A definição da origem desta população é bastante complexa na argumentação de Burton. Importa entretanto, notar que alguns dos principais instrumentos utilizados por ele para atingir seus objetivos são a história antiga e a Bíblia, além disto, em uma nota sobre a origem dos egípcios, Burton realiza especulações sobre um possível parentesco entre as línguas semíticas e jaféticas, ou entre o árabe e o latim, por exemplo. (Burton, 1964 : 76 - 81 vol 1).
} 
A descrição física assemelha-se a um retrato falado de corpo inteiro. Seria cansativo enumerar aqui todas as partes do corpo descritas pelo autor nestas páginas. Basta notar que praticamente nada é deixado de lado, desde o cabelo, passando por todos os elementos da feição, até as canelas e os dedos. Trata-se, na verdade, da construção de um tipo ideal, pois a impressão é que o autor escolheu um representante da comunidade e descreveu-o com a maior quantidade de detalhes possível. Não se trata de formas mais gerais, mas sim de definições estritas de formato, que não permitem muita variação. Talvez esta tenha sido a estratégia do autor para reforçar a afirmação que vem logo em seguida, de que os beduínos não se misturam com outros povos, pois, após este retrato falado de corpo inteiro, a afirmação subseqüente é que "este é o beduíno, e este ele tem sido por eras". ${ }^{6}$

O passo seguinte para a caracterização do beduíno é a sua descrição moral, por assim dizer. Como já se notou, tratava-se de uma população “nobre”, que apresentava qualidades morais elevadas. Características como "generosidade", "determinação", e "gentileza" vêm sempre acompanhadas de uma tentativa de explicação dos fatores que levaram aquela sociedade a apresentá-las.

Uma das razões sugeridas pelo autor que colaboravam para a configuração de uma sociedade "gentil" diz respeito ao lugar da mulher nesta sociedade, e merece atenção aqui, pois permite perceber a criação de um juízo novamente favorável a sociedades "puramente selvagens". Assegurando a existência do sentimento de "amor" entre os beduínos, Burton menciona que a mulher era respeitada e honrada diferentemente da sua posição nas sociedades “semi-civilizadas", pois:

"Quando o bárbaro torna-se semi-bárbaro, como eram os autores clássicos de Grécia e Roma, então, as mulheres caem de sua posição apropriada na sociedade e tornam-se meros artigos de luxuria e afundam na mais baixa condição moral." (Burton, 1964: 90, vol. 1).

A demonstração do cavalheirismo entre os homens e da honra entre as mulheres aparece fortemente assentada sobre exemplos retirados da literatura e da história árabe, numa argumentação que só seria possível a um profundo conhecedor destes dois campos.

\footnotetext{
${ }^{6}$ Embora de origem mestiça, a conservação de suas características físicas por longo período de tempo, parece conferir certa pureza a sua "raça". (Burton, $1964: 84$ vol 1).
} 
Entretanto, apesar de Burton efetuar sua demonstração com base na história e na literatura árabes, é na permanência de costumes ancestrais, e não na sua transformação, que pode ser percebido o valor da pureza de cada raça. E os costumes dos beduínos parecem ser tão fixos quanto seu tipo físico. Para Burton, estes costumes e instituições, "criados pelo seu clima, sua natureza e suas necessidades", permaneciam iguais aos de seus ancestrais, desde uma época anterior a Maomé, e deveriam permanecer "até que não sobrasse nenhum vestígio da Ka'abah" (a pedra sagrada do templo de Meca). (Burton, 1964 : 109 vol. 2)

Notem-se alguns dos elementos utilizados pelo autor para realizar a sua "construção" do beduíno. Primeiramente a utilização do texto bíblico e da lingüística como recursos auxiliares na comprovação da origem desta população, em segundo lugar, a descrição dos costumes com ênfase na explicação das causas e na utilização da literatura e da história árabe como fontes, elementos estes que permaneciam coerentes com a descrição dos "selvagens" das montanhas azuis indianas, embora a caracterização do beduíno apresentasse uma estruturação bastante mais definida.

Antes de se analisar a referência à população centro africana, é importante mencionar outro relato de Burton ainda nesta mesma década, que pode lançar luz sobre a transformação em suas concepções neste período.

Em First Footsteps in East África, publicado em 1856, resultado de uma viagem ainda em 1854, a descrição privilegiada é a dos Somalis, em um capítulo significativamente intiltulado "Os Somalis, suas origens e peculiaridades". Diferentemente dos beduínos ou dos Todas, os Somalis não mereciam mais a definição de "nobres”, pois:

Os nativos do país são essencialmente comerciais: eles caíram no barbarismo em razão de sua condição política[...]mas eles parecem conter material para uma regeneração moral (Burton, 1987: XXIX)

A estrutura formal da descrição é praticamente idêntica à do beduíno, começando por uma recuperação da origem (neste caso indubitavelmente mestiça), seguida de uma descrição física detalhada e de considerações sobre a moral desta população.

Dados significativos que aparecem neste relato, e que não apareciam nos anteriores, são as primeiras referências a características determinadas pela "raça" " Em sua viagem para Meca, em nenhum momento Burton recorreu a características raciais para explicar qualquer peculiaridade dos beduínos. Sua fonte sempre foi outra: a história, ou a 
literatura, ou mesmo as generalizações orientalistas. Aqui, estas informações não conseguem mais responder totalmente aos seus questionamentos, pois o autor não consegue recorrer às mesmas ferramentas com as quais construíra os beduínos.

Algumas idéias podem ser agrupadas de acordo com as descrições populacionais analisadas até este momento, na tentativa de compreensão das construções de Burton no que diz respeito à representação populacional. A busca da origem, assentada, como se viu, em comparações lingüísticas (como nos selvagens da Índia); a valorização do elemento cultural puro; a crença na possibilidade de regeneração moral; entre outros fatores, levam a acreditar que Burton estivesse se movimentando dentro de um modelo degeneracionista, no qual o contato parece gerar a degeneração moral ${ }^{8}$. Mesmo neste relato sobre a África Oriental, no qual começam a surgir análises baseadas nas características raciais da população, a regeneração moral ainda é possível.

O importante, porém, é notar que Burton parecia realmente pensar ainda dentro de modelos degeneracionistas, uma vez que podia idealizar o selvagem, valorizar suas tradições, e inferir as possibilidades de regeneração. Ainda que se possa avaliar como evolucionista o fato de que ele pensava em estágios de civilização, este evolucionismo é muito ambíguo e certamente não linear.

Em seu relato sobre a região centro-africana, este modelo parece sofrer alterações significativas. Nada mais havia no "selvagem" que fosse merecedor de admiração, parecia-lhe um ser incompreensível. Faltavam a Burton os instrumentos dos quais dispunha em maior ou menor grau em suas viagens anteriores, a saber, o conhecimento da linguagem, dos costumes e da história da região descrita. De fato, para Burton a ausência de história é um dos elementos que qualificam a região centroafricana visitada. Em clara oposição à antiguidade e nobreza dos beduínos, ou mesmo à possibilidade de regeneração dos Somalis, os africanos constituíam uma "raça nova", e a etnologia era a "única feição interessante” da África. (Burton, 1995: 88)

\footnotetext{
${ }^{7}$ Como exemplo, numa referência ao cansaço apresentado por seus acompanhantes numa caminhada, Burton afirma: "Eu tive então uma oportunidade de ver quão fraca é a raça somali. [...] Isto não pode se originar da dieta pobre, pois os cidadãos, os quais vivem generosamente, são ainda mais fracos que os beduínos; é uma particularidade da raça." (Burton, 1987 : 114 vol 1)

${ }^{8}$ De fato, Nancy Stepan sugere que até a década de 50 do século XIX, "tradicionalmente, a degeneração do homem de um estágio originário de civilização era visto como tão provável como seu avanço progressivo". (Stepan, $1987: 56)$.
} 
A "raça" africana era insistentemente classificada como "infantil", "criança", embrionária", entre outros termos, como forma de reafirmar sua crença no estágio de "evolução" daqueles povos. (Burton, 1995 : 491 - 499)

Juntamente com esta nova caracterização do selvagem, surge uma utilização muito mais ampla do conceito "raça" como determinante de características gerais da população. O parágrafo que segue é o primeiro de seu ensaio "O Caráter do africano oriental", colocado no final de seu relato, e demonstra bastante claramente algumas das idéias de Burton então:

"O estudo da psicologia na África Oriental é o estudo da mente rudimentar do homem, quando sujeita à ação da natureza material, ele nem progride nem retrocede. Ele pareceria mais uma degenerescência do homem civilizado do que um selvagem erguendo-se ao primeiro passo, não fosse sua aparente incapacidade para o aperfeiçoamento." (Burton, 1995 : 489).

O "selvagem" parecia incapaz de aprendizado, e talvez unicamente por esta característica, não poderia mais ser considerado uma degenerescência moral, mas somente um ser infantil, limitado por características intrínsecas à sua "raça".

A grande mudança que ocorre neste texto, com relação aos anteriores, é mesmo a classificação do selvagem como criança, e dela derivam uma série de conseqüências. Uma delas é o surgimento de uma tendência ao poligenismo, pois, para considerar o selvagem africano como "infância" da humanidade, a estratégia de Burton é afirmar que seu intelecto é limitado, portanto intrinsecamente diferente do intelecto do europeu. Outra delas é a adoção de um pensamento de certa maneira evolucionista, condicionado pelas características raciais, especialmente no que diz respeito à limitação do intelecto. Ainda que o pensamento evolucionista esteja em aparente contradição com as tendências poligênicas e afirmações de limites raciais.

A idéia de que havia estágios de civilização diferenciados e que tendiam ao progresso em direção à civilização européia, barrados, talvez, por características inerentemente raciais, parece estar bastante clara neste momento para Burton, como nos indica esta passagem sobre a essência do fetichismo:

"Fetichismo é uma superstição rude e sensual, a fé de um medo abjeto, e de raças infantis que ainda não se elevaram, e são, talvez, incapazes de elevarem-se 
ao teísmo - a religião de amor e a crença dos tipos mais elevados da humanidade." (Burton, 1995 : 501)

A experiência de Burton nesta viagem pode ser resgatada para elucidar as aparentes contradições em suas descrições populacionais. Nesta viagem, Burton esteve doente durante boa parte do tempo, não conseguiu aprender a linguagem dos nativos - que sempre havia sido um dos seus principais instrumentos de coleta de informações em viagens anteriores - e, portanto, tinha grandes dificuldades de comunicação, além de não possuir muitos conhecimentos anteriores das populações presentes nas regiões pelas quais viajava.

As dificuldades de compreensão de Burton em relação ao africano, derivadas das condições adversas da viagem e da ausência de instrumentos lingüísticos e históricos, parecem empurrá-lo para explicações antes menos importantes em seu esquema descritivo. Tem-se a impressão de que ele não consegue reproduzir seu esquema degeneracionista e passa a pensar de outras maneiras. Entretanto, ao mesmo tempo em que parece assumir um caráter evolucionista, ao classificar o africano como criança, busca a explicação da sua situação em supostos limites raciais, que o aproxima de concepções poligênicas e, conseqüentemente, não dinâmicas, mas estáticas quanto ao desenvolvimento ao longo do tempo. Um poligenismo evolucionista parece ser relativamente contraditório, mas é justamente esta contradição que permite representar a ambigüidade do pensamento de Burton neste momento. Sua própria experiência africana é relativamente contraditória: sua viagem foi ao mesmo tempo um sucesso e um fracasso, pois, embora tenha conseguido atingir o tão desejado "mar de Ujiji”, ou lago Tanganika, como foi rebatizado por ele, não conseguiu demonstrar que era ali a origem do rio Nilo (e de fato não era). E embora o relato possuísse o valor de afirmação do poder europeu sobre a região, Burton sentiu na pele todas as dificuldades da viagem, inclusive a desagradável experiência de descobrir que, sem os africanos, não teria sido possível a realização do seu grande feito, o grande feito europeu, isto é, a tomada de posse simbólica de um dos grandes lagos interiores da África central. ${ }^{9}$

\footnotetext{
${ }^{9}$ Burton menciona sua dependência inegável dos nativos africanos e o processo de negociação no qual cede a suas vontades durante a descrição de um dos principais componentes de sua caravana, o africano Kidogo, que, tendo se recusado a obedecer a ordens, consegue finalmente suas regalias, uma vez que Burton percebe que "sem eles eu seria forçado a retornar à costa" ." (Burton, 1995 : 111).
} 
A esta situação experiencial contraditória, soma-se a dificuldade de compreensão em razão da ausência de elementos que Burton possuía quando de suas outras viagens, a Meca e a Somália, ou seja, do recurso à história, das suas fontes e informantes nativos, e da própria boa vontade que podia ter em relação aos beduínos, em virtude de seu conhecimento.

Nota-se, portanto, uma interferência direta das condições da viagem e das experiências do contato nas transformações das concepções do autor ao longo deste relato. Em experiências anteriores, o conhecimento da língua e, em certa medida, da história das regiões através das quais havia viajado, permitia a Burton um tipo de descrição que não era mais possível na África Central. A situação delicada na qual Burton esteve em contato com os africanos moldou de certa maneira suas concepções a respeito destas populações, da mesma forma que seus esquemas classificatórios e descritivos não serviam mais para descrever esta nova experiência.

Seus modelos de descrição populacional continuavam a se alterar, e as contradições presentes em seu livro sobre a África Central repercutiram em seus relatos posteriores, na qual sua posição em relação às populações descritas estava assentada sobre uma outra legitimidade, não mais o militar da Índia, ou o aventureiro europeu da Arábia e da África, mas sim na condição de representante consular britânico, nas viagens que realizou para a África Ocidental e para o Brasil.

\section{0 período consular}

A primeira experiência consular de Burton foi na ilha de Fernando Pó, entre 1861 e 1864. A ilha era uma possessão espanhola situada no Golfo da Guiné, e havia sido importante base para as atividades antiescravistas britânicas durante boa parte da primeira metade do século XIX.

A viagem que deu origem ao relato "Wanderings in West África" apresenta características bastante diferentes das anteriormente analisadas aqui. Enquanto o relato sobre a Índia partia da perspectiva do militar com longo período de residência local e as viagens da década de 1850 apresentavam a perspectiva do explorador aventureiro que contava com alguns meses de observação, esta apresentava as impressões oriundas de uma viagem de navio da Inglaterra até Fernando Pó, que contava com paradas de apenas algumas horas em cada porto africano. 
Apesar de não contar com as descrições minuciosas e detidas dos livros anteriores, este relato apresenta-se como lugar privilegiado para se analisar as opiniões de Burton quanto à política externa britânica com relação à África Ocidental, pois, para preencher as lacunas descritivas resultantes do pequeno tempo de observação, e também de certa forma imbuído de sua nova posição consular, Burton alonga-se especialmente nos assuntos referentes à ação estatal inglesa na região.

Suas opiniões, como quase sempre, são aparentemente ambíguas. Ao mesmo tempo em que defende a intervenção estatal baseada no uso da força para fazer valer os interesses econômicos e expansionistas da coroa na costa ocidental africana, valoriza a idéia do livre comércio como forma legítima de atuação ${ }^{10}$.

A contradição aparente entre liberalismo econômico e intervencionismo político no posicionamento de Burton em relação à ação inglesa na África Ocidental resolvese também na conceituação do africano neste relato. De fato, o negro, embora muito inferiorizado, aparece caracterizado como capaz de galgar alguns passos em direção a um processo civilizador, mas somente sob a tutela européia.

Apesar disto, em nenhum outro momento, seus juízos para com a população "selvagem" aparece de forma tão negativa como neste livro. As referências aos negros estão recheadas de adjetivos pejorativos tais como "gorilas", "elo perdido", "cascavel”, entre outros (Burton, 1991b: 207, vol. 1). De fato, a diferença para com a população européia nunca pareceu maior para Burton como nas opiniões expressas neste livro, o parágrafo seguinte traz um comentário sobre um dos negros que estavam no navio, e mostra-se revelador da opinião do autor então:

"Da humilde aspiração de ser considerado como homem, nosso amigo preto agora corajosamente avança em seus objetivos de igualité and fraternité, como se pu-

\footnotetext{
${ }^{10}$ A contradição entre intervenção estatal na organização político-legal nas regiões oeste-africanas e o liberalismo econômico é apenas aparente. (Dias, 1975) que a idéia de expansão imperial não era apanágio de nenhuma facção política e que, desde o começo do século XIX, mesmo os liberais defendiam um programa expansionista, ainda que esta expansão estivesse justificada por motivos diferentes, ou seja, enquanto os conservadores justificavam e legitimavam a expansão através de uma ideologia humanitária e filantrópica, com intuito "civilizador", os liberais enxergavam a necessidade de expansão sob uma ótica econômica, com objetivo de criar mercados e promover desenvolvimento econômico nas colônias.
} 
desse haver igualdade entre o rei e o bobo! O ser que 'não inventa nada, que não origina nada, que não melhora nada, que é capaz somente de cozinhar, cuidar e trapacear;' que não tem nem energia nem indústria, salvo em raros casos que provam a regra! o escravo auto constituído, que se delicia na sujeição a e na imitação das raças superiores." (Burton, 1991b: 175, vol. 1).

Ao mesmo tempo em que esta diferença aumentava, entretanto, pode-se inferir que Burton conhecia o livro de Darwin, A origem das Espécies, publicado dois anos antes, pois não são infreqüentes as referências à "seleção das espécies", e raciocínios tais como a potencialidade transformadora do isolamento prolongado ${ }^{11}$. Por outro lado, seu relato sobre a África ocidental foi lançado em 1863, no mesmo ano em que Burton presidia a primeira reunião da London Anthropological Society, uma instituição com fortes tendências a interpretações poligênicas no que diz respeito à origem da humanidade ${ }^{12}$.

Neste livro, Burton divide toda a população africana em duas "raças", denominadas significativamente de "nobre" e "ignóbil". A primeira delas é caracterizada como norte-africana e teria sido semitizada por migrações islâmicas anteriores ao século X da era cristã. Em sua avaliação desta população, contradizendo suas interpretações anteriores, o contato com povos mais avançados não era mais necessariamente um fator de degeneração, ao contrário, sob influência do sangue e da religião árabes, o selvagem africano havia dado "primeiro passo no progresso moral, o qual custa muito para a natureza bárbara" (Burton, 1991b: 180, vol. 1).

Seguindo o mesmo raciocínio, a parcela restante da população africana permanecia "pura", sem longos contatos anteriores com civilizações mais avançadas, o que fazia com que permanecesse com o "intelecto fraco", com a "moral deficiente", a "destrutividade altamente desenvolvida", entre outras características pouco abonadoras. Ainda assim, a despeito do grande fosso que separava africanos de europeus, e da filiação de Burton à sociedade antropológica de Londres com suas idéias poligênicas, os limites "raciais" africanos poderiam sim ser alargados. Como se notou, os norte-

\footnotetext{
${ }^{11}$ Embora Burton no caso estivesse discutindo questões referentes à língua e não a espécies.

${ }^{12}$ Para uma apreciação do contexto da fundação da London Anthropological Society, e de suas principais tendências, ver Stocking, 1987: 238 - 273.
} 
africanos já haviam dado o "primeiro passo" em direção ao progresso moral, e os demais também poderiam fazê-lo, obviamente, sob a tutela européia. Segundo Burton,

"Muitos que já estudaram o caráter do africano darão suporte ao testemunho da verdade, que o africano é criatura muito mais inocente e natural quando nunca foi trazido ao alcance da vida civilizada. Mas a falta não está assentada em nenhuma incapacidade para civilização, mas no nosso método de fornecê-la." (Burton, 1991b: 221, vol. 1).

Ainda segundo o autor, bastaria observar a colônia de Serra Leoa para que se percebesse "uma aplicação particular de uma lei universal - o desenvolvimento gradual da mente humana" (Burton, 1991b: 221, vol. 1). Como se pode notar, a caracterização do negro desta forma, ou seja, atrasado, mas apto a evoluir sob a norma européia, resolve em parte o problema da contradição aparente entre intervencionismo político e administrativo e liberalismo comercial.

De outro ponto de vista, claramente já surge neste relato um Burton crente em alguma forma de evolução. Isto faz pensar que, ao mesmo tempo em que as diferenças podem se acentuar entre as populações, a questão da origem não parece mais tão importante como elemento definidor destas diferenças quanto em outros relatos do autor. E embora se aproxime de considerações poligenistas, ele nunca se manifestou, ao menos nos textos observados aqui, categoricamente sobre esta questão; ao contrário, pode-se afirmar que Burton nunca questionara a unidade da criação humana e, ao longo do tempo, o que fez foi buscar elementos para explicar uma disparidade cada vez maior frente a seus olhos europeus.

Suas referências à população africana encaixam-se perfeitamente nas pretensões de domínio europeu, mesmo que, para assegurar a possibilidade de evolução dos africanos, fosse preciso questionar certos modelos de fixidez da antropologia física predominante na London Anthropological Society, da qual presidira a primeira reunião.

Em seu relato sobre o Brasil, as ambigüidades em suas descrições populacionais continuam presentes. Buscar enquadrá-lo em algum modelo, e desta forma reduzir suas descrições a aplicações da teoria racial européia, demonstra-se altamente ineficaz.

De fato, costuma-se pensar numa oposição entre monogenismo e poligenismo, sendo que o primeiro aparece associado a conceitos como a fixidez do tipo racial, a análises da antropologia física, à subordinação da cultura à raça, entre outros, enquanto 
o segundo associa-se à etnologia, à diferenciação ao longo do tempo devido a fatores externos, como o clima, e, logo, a concepções evolucionistas. Entretanto, estas oposições não resolvem a complexa questão do pensamento sobre o desenvolvimento do homem e da civilização na segunda metade do século XIX. Muitas vezes surgiam elementos aparentemente contraditórios numa mesma interpretação ${ }^{13}$.

As descrições de Burton desafiam as tentativas de transformar estas oposições em blocos rígidos e impermeáveis. Como se viu, enquanto se movimentava dentro de padrões que se aproximavam de idéias monogenistas, podia falar também em degeneração; além disso, durante a década de 1850, ao mesmo tempo em que se nota simpatia para com idéias poligenistas, começam a surgir, em seus relatos, tendências que sugerem um pensamento evolucionista.

No Brasil, Burton não aparenta livrar-se destas ambigüidades. Seu relato está recheado de referências à inexorabilidade do progresso da nação. Segundo ele, a civilização vicejaria necessariamente no império, bastando para isto que se desenvolvessem linhas de transporte e conseqüentemente se ampliassem as relações comerciais com a Europa, em especial com a Inglaterra. Havia, entretanto, um obstáculo para este progresso, qual seja, o grande contingente de negros na população brasileira. Este problema seria resolvido da seguinte maneira: o negro, a despeito de suas afirmações poucos anos antes na África Ocidental, não era mais perfectível, e estava fadado a desaparecer, uma vez cessada a corrente migratória forçada com o fim do tráfico.

"Como o índio é morto pela aproximação da civilização, à qual ele resiste em vão, assim também o homem negro perece pela cultura à qual ele serve como humilde instrumento." (Burton, 1869: 270, vol. 1).

Pouco antes, no capítulo anterior, Burton menciona que o "negro no Brasil é um exótico, é difícil mantê-lo vivo, como o próximo quarto de século irá provar" (Burton, 1869: 242, vol. 1). Nesta passagem, ele estava se referindo à impossibilidade

\footnotetext{
${ }^{13}$ Pode-se mencionar como exemplo a passagem de Alfred Russel Wallace, nominalmente monogenista, mas que também se permitia afirmar que a diferenciação das raças humanas havia se dado há tanto tempo que se poderia então falar que "há muitas, originalmente distintas, raças de homens". (Stocking, 1968).
} 
de adaptação do negro em novos ambientes. Este foi um conceito desenvolvido, entre outros, pelo Dr. Robert Knox, um dos poucos e mais ferrenhos defensores do poligenismo na Inglaterra nas décadas de 1840 e 1850.

Entretanto, em clara contradição com estas afirmações, durante suas descrições do "mineiro" (o habitante de Minas Gerais), Burton sugere que esta população sofrera alterações fenotípicas e morais oriundas da ação do clima, num processo denominado por ele mesmo de "crioulização" (Burton, 1869: 391, vol. 1), mesmo sabendo que estas asserções iam de encontro a algumas das idéias mais caras ao modelo poligenista, tal como a crença na fixidez do tipo racial. Segundo ele,

"Esta crença no crioulismo pode parecer herética, e se for, quanto antes isto for confirmado melhor. Mas os exemplos citados para provar a absoluta permanência da raça, como os parses na Índia Ocidental e os judeus em Áden, não tocam na questão, estas tribos moveram-se numa pequena área...” (Burton, 1869: 391, vol. 1).

Apesar de considerar que a verdade sobre a questão da origem e desenvolvimento da humanidade estava em algum lugar entre as asserções "monogenistas ortodoxas", segundo as quais todas as diferenças entre as raças seriam unicamente advindas das variações climáticas e geográficas, e os poligenistas radicais, segundo os quais a raça era um caractere fixo e imutável, e que "raça era tudo na história", referindose diretamente ao Dr. Robert Knox (Burton, 1869: 390, vol. 1), Burton colocavase, ao menos nominalmente, ao lado dos últimos. Assinou seu relato como "ex-presidente da Sociedade Antropológica de Londres" e, como se nota, considera suas asserções sobre a crioulização como possivelmente "heréticas", embora supostamente derivadas da observação direta.

Em outros momentos do texto, Burton pagou seu tributo à antropologia física durante a descrição da população mineira, a qual aparece retratada minuciosamente numa linguagem quase fisiológica ${ }^{14}$, fazendo surgir finalmente uma descrição física com os termos mais próprios.

\footnotetext{
${ }^{14}$ A sua descrição da pele, por exemplo aparece nos termos: " A pele do mineiro é de um marrom escuro morno, raramente iluminada nas bochechas, e muitas vezes amarelada pela secreção biliar, pela obstrução dos dutos, ou pelo excesso de ácido no sistema, tingindo os vasos sangüíneos do sistema."(Burton, 1869: 392, vol 1).
} 
Como já foi mencionado, a utilização ambígua e simultânea de elementos poligenistas e monogenistas não era propriamente incomum. No caso de Burton, a negação da capacidade do negro em aclimatar-se e, ao mesmo tempo, a consideração sobre a crioulização da população adventícia européia na região de Minas Gerais, e a rigor toda sua descrição populacional, podem ser melhor compreendidas a partir da observação de outros fatores.

Em sua estadia no Brasil, Burton manifestou-se em concordância tanto com as intenções de desenvolvimento da atividade comercial entre Brasil e Inglaterra, quanto com certas especificidades ideológicas de parte da elite intelectual brasileira. Segundo Ilmar R. Matos, no início da segunda metade do século XIX, os "fundadores e consolidadores do império brasileiro" tinham "os olhos na Europa e os pés na América": os "olhos na Europa" pela aspiração de incluir o Brasil entre as nações civilizadas, como Estado soberano, que acompanhara o curso das conquistas dos Estados europeus e de suas instituições constitucionais e liberais; os "pés na América" pela necessidade de conferir especificidade a esta nação, que guardava em si as tradições escravistas, e, consequentemente, precisava garantir a conservação de uma ordem hierárquica interna pelo controle do contingente populacional excluído.(Matos, 1987: 173).

As possibilidades de desenvolvimento do Brasil, alavancadas pelo estreitamento das relações comerciais com a Inglaterra e possivelmente pelo estabelecimento de um fluxo de imigração européia, esbarravam no contingente populacional negro. A equação foi resolvida por ele, como se viu, através da condenação desta parcela da população ao desaparecimento, uma vez que não era capaz de se aclimatar. Já a população de ascendência européia, "crioulizada" pela ação climática, estava perfeitamente adaptada e apresentava condições plenas de contribuir no cumprimento de seu papel para o desenvolvimento do Brasil e consequentemente em seu caminho em direção a uma civilização próxima à forma européia.

Burton havia permanecido dois anos no Brasil, em contato direto com uma parcela da elite imperial e coadunava parcialmente com suas idéias. Referia-se a Perdigão Malheiro quando defendia a abolição gradual da escravidão, condenava a própria pressão inglesa para a extinção da instituição escravista, fazia coro à apregoada necessidade de estabelecimento de imigração européia. Novamente, suas descrições populacionais estavam sujeitas às condições de sua viagem, aos seus interlocutores e aos caminhos do pensamento etno-antropológico europeu. 


\section{Considerações Finais}

Parece relativamente claro que as descrições populacionais de Burton sofrem significativas mudanças ao longo do tempo. Num primeiro momento, foi possível notar como a idéia de manutenção e expansão do império inglês na Índia influenciou as descrições das populações sob regra portuguesa e inglesa. Burton defendeu um programa de anexação militar das províncias indianas, e não simplesmente o domínio de rotas comerciais como acreditava terem feito os portugueses. Para sustentar o "império de opinião", expressão com a qual ele definiu o caráter do domínio inglês na Península Indiana, os ingleses não deveriam residir muito tempo na região em virtude da possibilidade de degeneração derivada, tanto da indesejada miscigenação, bem como da ação do clima, o que levaria à corrosão da imagem de superioridade sustentada pelos europeus na Índia, tal como acontecera aos portugueses, submetidos a estes elementos. Ainda em seu relato sobre a viagem indiana ( Goa and the Blue Mountains), encontra-se uma descrição da população selvagem, composta pelos habitantes das montanhas, que, segundo ele mesmo, nunca chegariam a representar nenhuma ameaça significativa à presença inglesa por ali. Nestas passagens, notouse um Burton que aceitava ambiguamente a influência climática no desenvolvimento físico e moral da população, e que se movia dentro de modelos estáticos ou degeneracionistas, baseados numa crença na origem una da humanidade. Seus termos eram etnológicos, como eram os da corrente mais influente na Inglaterra de então, no que diz respeito à representação das populações não européias.

Foi possível num segundo momento, notar as transformações nas representações do autor em três diferentes relatos escritos na década de 1850 (Personal narrative of a pilgrimage to Al Medina and Mecah, First Footsteps in East Africa e The Lake Regions of Central Africa), nos quais Burton se coloca na perspectiva do aventureiro explorador. Notou-se, então, como Burton utilizou-se enquanto pôde de um conhecimento erudito, que ele havia adquirido anteriormente a respeito da história, da literatura e da religião dos lugares por onde passou, para conformar a descrição destas populações. Estas características estão presentes especialmente em seu relato de viagem sobre a Península Arábica, mas também aparecem, em certa medida, em seu livro sobre a região somali. Nestes dois livros, Burton ainda utilizava-se, para descrever a população, de representações estáticas ou degeneracionistas, claramente 
monogênicas, cuja explicação para sua origem e características recaía sobre a história destes lugares, utilizando muito pouco de explicações assentadas sobre conceitos tais como raça, termo este que, aliás, apresentava-se bastante impreciso nestes textos. Sua perspectiva de relativa identificação com os preceitos da religião islâmica certamente contribuiu para sua caracterização do beduíno como um nobre selvagem, e seu conhecimento da história e da literatura árabe tornou possível recuperar elementos diversos para afirmar esta suposta nobreza. Ainda assim, a superioridade natural dos povos europeus nunca parecia questionada; mesmo as noções de honra e do lugar da mulher na sociedade, que indicavam a nobreza da população beduína, eram valores representativos das próprias sociedades européias, ou seja, representavam para os europeus sinais de sua própria civilização.

Em seu terceiro relato na década de 1850, suas descrições parecem sofrer uma transformação fundamental, o africano "criança", embora mais parecesse um ser degenerado, deveria ser representado como um selvagem dando seus primeiros passos em direção ao progresso. A razão disto era a sua "aparente incapacidade para se aperfeiçoar". Ao utilizar este tipo de representação, Burton caminhava em direção a concepções evolucionistas ao mesmo tempo em que, ao creditar à raça a responsabilidade do desenvolvimento atrasado do africano, e considerá-lo, portanto, intrinsecamente diferente do europeu, avançava ambiguamente em direção a concepções poligênicas quanto à origem da humanidade. A experiência pessoal resultante desta viagem épica surge também como bastante ambígua. Havia sido, ao mesmo tempo, um sucesso e um fracasso: às inúmeras dificuldades, como doenças, deserções, dependência em relação aos selvagens africanos, opõem-se o retorno e a "vitória" européia sobre as adversidades, representada materialmente pelo relato publicado. Além disto, o objetivo principal da viagem não foi definitivamente alcançado, ou seja, a questão da definição das origens do Nilo permanecia como incógnita. De fato, esta controvérsia gerou um debate deveras desgastante para a imagem do próprio Burton.

Foi com o correr da década de 1850 que explicações baseadas na determinação racial ganharam mais importância no modelo descritivo de Burton, e foi nesta mesma década que houve uma maior penetração na Inglaterra de explicações sobre as diferenças nas várias populações do mundo baseadas em características raciais - com a raça determinando as possibilidades de evolução e desenvolvimento do homem. Isto parece refletir-se de certa maneira nas descrições populacionais de Burton, 
entretanto, ele ainda nomeou os capítulos nos quais tratou destes assuntos como "Geografia e Etnologia das regiões".

Finalmente, na década de 1860 uma nova perspectiva entra em cena, derivada da posição de cônsul na África Ocidental e no Brasil. A esta nova perspectiva de representante oficial do império britânico, alia-se a associação de Burton à London Anthropological Society, teoricamente rival da etnologia inglesa neste período. A sua representação das populações não européias, especialmente do negro africano ocidental, recorre fortemente à determinação racial como elemento explicativo da inferioridade destas com relação a populações da Europa. É significativo, entretanto, que este arcabouço teórico de inferioridade racial e possibilidade de desenvolvimento destas regiões condicionada ao domínio europeu correspondessem quase exatamente às idéias do autor sobre as políticas inglesas necessárias para que se ampliasse a zona de influência britânica no oeste africano.

O relato de Burton sobre a viagem ao Brasil, por sua vez, vem problematizar a sua filiação aos preceitos teóricos mais ortodoxos da antropologia física. O autor utiliza-se de elementos contraditórios para projetar o desenvolvimento do país. Desenvolvimento este condicionado à imigração européia e à conseqüente adaptabilidade do elemento europeu à nova região, ao mesmo tempo em que o negro e a escravidão estavam condenados à extinção no Brasil, justamente pela impossibilidade da assim chamada aclimatação. A noção de interferência de fatores externos, como o clima, na transformação fenotípica e moral da população, considerada "herética" pelos poligenistas mais ortodoxos, serve de maneira bastante ambígua para solucionar o problema da projeção de um futuro positivo para o Brasil e sua população, à exceção do negro, que estava fadado ao desaparecimento. Notou-se que este quadro projetivo se coadunava tanto com os interesses comerciais ingleses no Brasil quanto com as idéias abraçadas por parte da elite imperial, num momento em que já apareciam preocupações com o futuro das instituições escravistas no Império, e com os desenvolvimentos estruturais necessários para a manutenção da unidade do Estado Nacional consolidado.

Resta notar que as transformações nas descrições de Burton parecem concordar com períodos de alterações significativas das correntes teóricas mais influentes na Inglaterra quanto à questão da conceituação das populações não européias do mundo. Foi no final da década de 1850 que interpretações mais fortemente pautadas pela 
determinação racial ganharam espaço, especificamente na Inglaterra. Entretanto, as apropriações destas teorias por Burton foram seletivas e condicionadas tanto pelas suas experiências de viagem quanto pela posição na qual o autor se coloca para narrar estas experiências.

A relação de Burton com o discurso sobre as populações não européias que se desenvolvia na Inglaterra e em outros países da Europa, uma relação de apropriação seletiva e pessoal, leva a uma reflexão sobre a definição do termo "Orientalismo", oferecida por Edward Said em seu livro homônimo. Segundo este autor, o orientalismo é um discurso que estrutura e representa o oriente para os europeus, um discurso que negocia com o oriente " fazendo declarações a seu respeito, autorizando opiniões sobre ele, descrevendo-o, colonizando-o governando-o...”(Said, 1990, 15). A questão do pensamento europeu sobre o desenvolvimento do homem e da civilização, que envolve a observação, descrição e construção das populações não européias pode ser pensada desta mesma maneira como um discurso. Said sugere que o Orientalismo tinha uma posição tal de autoridade que influenciava necessariamente todas as pessoas que se propusessem a pensar ou escrever sobre o oriente, mas também faz uma importante ressalva, ou seja, que "isto não quer dizer que o orientalismo determine de modo unilateral o que pode ser dito sobre o Oriente, mas que ele é toda a rede de interesses que inevitavelmente faz valer seu prestígio [...] toda vez que aquela entidade peculiar, o ‘Oriente' esteja em questão.’(Said, 1990, 15).

Desta forma, há uma relação de criação entre a entidade discurso e cada enunciado em si que participa desta construção maior. A metáfora da rede, utilizada por Said, e, de fato, sua própria concepção de discurso são advém das definições de Foucault em Arqueologia do Saber. Neste texto, Foucault trata de cada enunciado como se fosse um "um nó em uma rede", ou seja, "preso em um sistema de remissões a outros livros, outros textos, outras frases." (Foulcault, 1985: 27). Mas também é importante pensar que cada nó é ponto constitutivo desta rede, e que ela própria é uma construção metodológica e seletiva e, sem qualquer um deles, poderia haver nela uma lacuna.

Enfim, o que se procurou neste trabalho foi tratar cada enunciado, ou, no caso, cada uma das descrições populacionais de Burton, como um ponto de ligação, mas também de descontinuidade, irrupção na trama de um discurso maior. Segundo Foucault, o enunciado está 
“...aberto à repetição, à transformação, à reativação; finalmente, porque está ligado não apenas a situações que o provocam, e a conseqüências por ela ocasionadas, mas, ao mesmo tempo, e segundo uma modalidade inteiramente diferente, a enunciados que o precedem e o seguem." (Foulcault, 1985: 27).

Desta maneira, este trabalho procurou apresentar cada um dos livros de Burton dentro de sua especificidade de enunciado único, ligado, portanto, às condições experienciais específicas que o tornaram possível, ao mesmo tempo em que cada um deles, dentro de certos limites, também amplia e discute e se relaciona com uma instituição discursiva maior que diz respeito ao pensamento europeu sobre as populações não européias do mundo. Assim, as transformações nas representações populacionais de Burton só podem ser compreendidas quando se percebe a relação de tensão construtiva entre cada enunciado e as condições que o tornaram possível, e um discurso maior, com o qual se relaciona.

\section{Referências Bibliográficas}

BHABHA, Homi. O Local da Cultura, Belo Horizonte, Editora da UFMG, 1998, 395p.

BURTON, Richard Francis. Explorations of the Highlands of Brazil; with a full account of the gold and diamond mines; also, canoeing down 1500 miles of the great river San Francisco, from Sabará to the sea. London, Tinsley Brothers, 1869, 2 vols.

Goa and the Blue Mountains or Six Months of Sick Leave. Nova Delhi, Madras, Asian educational services, 1991a, 382.

First Footsteps in East Africa or an Exploration of Harar. New York, Dover Publications, 1987, 2 vols.

Personal Narrative of a Pilgrimage to Al Madinah and Mecah. New York, Dover Publications, 1964, 2 vols.

The Lake Regions of Central Africa. New York, Dover Publications, 1995, 572.

Wanderings in West Africa. New York, Dover Publications, 1991b, 2 vols.

COHEN, Benjamin. The question of imperialism: the political economy of dominance and dependence. New York, Basic Book, 1973, 280p.

DIAS, Maria Odila Leite da Silva. "O mito da descolonização liberal na Inglaterra Vitoriana”. Revista de História, volume LII, 1975, 297 - 314. 
GERBI, Antonello. O Mundo Novo. História de uma polêmica (1750-1900). São

Paulo, Cia das Letras, 1996, 807p.

MCLYNN, Frank. From Sierras to the pampas. Century, Londres, 1991, 305p.

GOULD, S. J. A Falsa Medida do Homem. São Paulo, Martins Fontes, 1999, 369p.

FOULCAULT, M. A Arqueologia do saber. Rio de Janeiro, Forense Universitária, 1995, 239p.

MATOS, Ilmar R. O Tempo Saquarema. São Paulo, Hucitec, 1987, 300p.

POLIAKOV, Leon. O Mito Ariano: ensaio sobre as fontes do racismo e dos nacionalismos. São Paulo, Perspectiva: USP, 1974, 329p.

PRATT, Mary L. Os olhos do império, relatos de viagem e transculturação. Bauru, Edusc, 1999, 393p.

RICE, Edward. Sir Richard Francis Burton, o agente secreto que fez a peregrinação a Meca, descobriu o Kama Sutra e trouxe as mil e uma noites para o ocidente. São Paulo, Cia das Letras, 1991, 529p.

SAID, Edward. Orientalismo. São Paulo, Cia das Letras, 1990, 370p.

STAFFORD, Robert. "Scientific Exploration and Empire", in PORTER, Andrew. The Oxford History of British Empire, vol. 3. Oxford and New York, Oxford University Press, 1999, p. 294 - 315.

STEPAN Nancy. The idea of Race in Science. Oxford, MacMillan, 1987, 230p.

STOCKING, George, Victorian anthropology. New York, Free Press, 1987, 429p.

STOCKING, George. "the persistence of polygenist thougth in post Darwinian anthropology", in STOCKING, George. Race Culture and Evolution, New York, the Free Press, 1968, 46 - 68.

TAX, Sol. "The Settings of the Science of Man”, in TAX, Sol. Horizons of Anthropology, Chicago, Albine, 1964, 15 - 24. 